\title{
Spatiotemporal perspectives on urban energy transitions: a comparative study of three cities in China
}

\author{
Vanesa Castán Broto ${ }^{1 *} \mathbb{D}$, Daphne Mah², Fangzhu Zhang ${ }^{3}$, Ping Huang ${ }^{1}$, Kevin Lo ${ }^{2}$ and Linda Westman ${ }^{1}$
}

\author{
* Correspondence: v.castanbroto@ \\ sheffield.ac.uk \\ ${ }^{1}$ Urban Institute, University of \\ Sheffield, 219 Portobello, S1 4PD, \\ Sheffield, UK \\ Full list of author information is \\ available at the end of the article
}

\begin{abstract}
This paper develops an integrated framework to study the socio-spatial and temporal dimensions of urban energy transitions to investigate the development and spread of solar energy technologies in urban China. A comparative analysis of three case studies of solar energy transitions in the cities of Foshan (in Guangdong), Rizhao (in Shandong), and Wuxi (in Jiangsu) demonstrates the framework's applicability. The results map each city's trajectory towards low carbon energy. Transitions result from dynamic interactions among central and local governments, solar manufacturers, solar installers, and residents. Alongside industrial strategies, locally-specific factors have a determining influence on the eventual outcomes.
\end{abstract}

Keywords: Urban sustainability transitions, Solar technologies, Innovation pathways, Spatial embeddedness, China

\section{Science highlights}

- The research adds a temporal perspective to the Dimensions of Urban Energy Transitions (DUET) framework.

- Urban transitions in China are highly heterogeneous and shaped by place-specific factors.

- Cities' transition trajectories towards low carbon energy benefit from alignment between political priorities and industrial interests.

\section{Policy and practice recommendations}

- The phase model can support transition policymaking by supporting a staged diagnosis of specific moments in transition.

- Strategies to catalyze a rapid transition to solar energy need to acknowledge the territorial context of implementation.

(c) The Author(s). 2020 Open Access This article is licensed under a Creative Commons Attribution 4.0 International License, which permits use, sharing, adaptation, distribution and reproduction in any medium or format, as long as you give appropriate credit to the original author(s) and the source, provide a link to the Creative Commons licence, and indicate if changes were made. The images or other third party material in this article are included in the article's Creative Commons licence, unless indicated otherwise in a credit line to the material. If material is not included in the article's Creative Commons licence and your intended use is not permitted by statutory regulation or exceeds the permitted use, you will need to obtain permission directly from the copyright holder. To view a copy of this licence, visit http://creativecommons.org/licenses/by/4.0/. 
- Transition governance needs to focus on long-term transformations, with planned changes occurring against the routine management of daily experiences and expectations.

\section{Introduction}

The Global Commission on the Geopolitics of Energy Transformation argued in 2019 that China could become "the world's renewable energy superpower," as it is "the world's largest producer, exporter and installer of solar panels, wind turbines, batteries, and electric vehicles" (GCGET 2019; p.40). New installations in China accounted for approximately $45 \%$ of global additions to Solar PV capacity and $74 \%$ of global additions to solar thermal capacity in 2018 (REN21 2019), even though the demand for both solar PV and solar thermal energy has been constrained at the national level and overall investment has declined.

The growth of the solar industry in China has made a substantial difference in the global energy transition (Urban et al. 2016). A common explanation is that the combination of strong public policies (enshrined in forward-looking Five-Year Plans) and the country's manufacturing capacity have made China a solar giant (e.g., Yuan and Zuo 2011; Hong et al. 2013). National policy has had a definitive influence on the solar transition in China (Liu and Shiroyama 2013). However, this is not the whole story. Complex layers of decision-making at regional and local levels influence the implementation and outcomes of any transition policy (Lo and Castán Broto 2019).

Socio-technical perspectives suggest that solar transitions are not the result of manufacturing alone (Rosenbloom et al. 2016). In China, the growth of solar generation capacity has happened alongside the integration of solar energy in socio-economic life. Many cities in China have been able to take advantage of the availability of technology to promote solar technologies in cities. A complex interplay between processes of innovation, local politics, and socio-spatial conditions enable urban energy transitions.

The research question is as follows: To what extent, how and why have urban areas in China facilitated technological innovations in solar energy and the subsequent spread of technology? The multi-phased model of innovation emphasizes the temporal evolution of transitions (Loorbach and Shiroyama 2016). This dynamic perspective on energy transitions complements a spatial framework, the Dimensions of Urban Energy Transitions (DUET) (Huang and Castán Broto 2018).

The case of China provides insights into the dynamics of innovation in local industries alongside parallel processes whereby such innovations become embedded in urban life. The energy transition in China follows long-term trajectories of support of solar industries, public interests, and deep transformations of the built environment that involve changing everyday practices of energy use.

The paper examines the cases of Foshan, Rizhao, and Wuxi, three cities known in China and internationally for driving solar energy transitions. Foshan is a leader in solar PV, while Rizhao and Wuxi are both leaders in solar thermal energy. Their urban trajectories reveal the progressive alignment over time of multiple actors in a transition that also depends on minor and incremental changes in everyday life.

Following this, Section 2 outlines the theoretical perspectives that inform the combined framework to analyze urban energy transitions. Section 3 introduces the methodology of this study. Section 4 first presents the urban trajectory in each case study 
alongside a multidimensional account of each urban transition. The paper concludes that a combination of local industrial strategies and societal changes at the urban level explain urban energy transitions in China.

\section{Understanding urban energy transitions: socio-spatial and temporal dimensions}

Cities are simultaneously vulnerable to energy challenges and serve as hotbeds for innovation and experimentation with energy technologies (Loorbach and Shiroyama 2016; Mah and Hills 2016). In the past two decades, cities around the world have become increasingly proactive in low carbon transitions (Bulkeley and Betsill 2013). Urbanization shapes energy demand but also offers opportunities to foster an energy transition, for example, through the construction of new low carbon infrastructures or the development of alternative models of low carbon urban living (Castan Broto 2019).

The literature on socio-technical transitions draws attention to the co-evolution of energy technologies and societal processes and the technological, sociocultural, and institutional changes that shape energy regimes (Kemp and Parto 2005). These sociotechnical perspectives on urban transitions emphasize the complex interplay of forces that stabilize and disrupt urban energy regimes (Frantzeskaki et al. 2017; Monstadt and Wolff 2015; Moore et al. 2018; Morlet and Keirstead 2013; Rutherford and Coutard 2014).

Transition scholars have claimed the need to revisit ideas of space in transitions to sustainability (Bergek et al. 2015; Berkhout et al. 2009; Binz et al. 2014, 2016; Coenen et al. 2012; Coenen and Truffer 2012; Hansen and Coenen 2015). This debate has led to the rise of new frameworks that address the particularities of specific environments in multiscalar transitions (Wieczorek et al. 2015).

\section{The dimensions of Urban energy transitions framework}

The DUET framework seeks to systematically analyze the socio-spatial and political interactions that shape urban energy transitions (Huang and Castán Broto 2018; Huang et al. 2018b). The focus is on delivering a context-sensitive analysis of energy transitions. The DUET framework focuses on three dimensions.

First, energy transitions are driven by innovation and experiments with emerging technologies alongside corresponding changes in the socio-technical configurations that facilitate innovation. In China, much of this relates to industrial innovation. In this case, the emergence and maintenance of socio-technical experimentation may follow a combination of at least six key processes: entrepreneurial experimentation, knowledge development and diffusion, guidance of the search, (niche) market formation, resource mobilization, and the creation of legitimacy (Hekkert et al. 2007; Negro et al. 2007). Successful socio-technical experimentation often involves the mobilization of four resources: specialized technological knowledge, financial investment, technology legitimacy, and niche markets (Binz et al. 2016). Previous studies have emphasized the significance of pioneering entrepreneurial activities in translating newly emerging technologies into concrete experimental actions for energy transitions.

Second, socio-technical experimentation occurs within a political context. Urban politics involve multiple practices of control, regulation, and contestation. The 
legitimization of innovations in a given context entails (among other things) the orchestration of actions of various actors with competing interests. Such actors are also involved in ongoing processes of collaboration, contestation, and conflict. The mobilization of the above four resources in socio-technical experimentation is highly politicized within place-specific contexts, whether in relation to the transformation of urban institutions, the confrontation of different interests, or the deployment of material agencies (Bulkeley et al. 2016; Rutherford and Coutard 2014). Following the insights of the existing literature, we identify three simultaneous urban political processes with the tendency to 1) destabilize urban regimes, 2) stabilize incumbent regimes, and 3) resolve urban material politics. Conflicts between different actors evolve with a changing local political discourse around possibilities for action and energy futures (Bulkeley et al. 2014). Existing urban institutions may hinder or adapt transitions. The material politics that follow radical physical alterations of the built environment also constitute energy transitions (Bulkeley et al. 2016; Hodson et al. 2017).

Third, the socio-spatial dimension adds a layer of complexity to the above dimensions. Spatial entanglements of energy systems are both preconditions and outcomes of transitional processes. On the one hand, specific places are always attached to or embedded within pre-existing sociospatial arrangements. Such conditions may promote or inhibit the emergence and maintenance of socio-technical experimentation (Castán Broto and Bulkeley 2013). On the other hand, place-based sociospatial arrangements are continuously (re)shaped by emerging socio-technical transitions. In this sense, sociospatial arrangements play the role of both medium (contextual enabling/disenabling factors) and consequence (sociospatial manifestations) of the integration of innovations with dynamic urban processes. Sociospatial arrangements reflect diverse aspects, including territorial proximities, technological relatedness, and spatial clustering, and the social and cultural embeddedness of urban experiences and practices around energy technologies. Territorial proximity indicates the intense relationship among proximity dimensions, local niche experimentation, and innovations (Boschma 2005). Following this, proximity can be the accessibility of resources and relatedness of local industries (geographical proximity), the shared knowledge base of various local actors on energy technologies (cognitive proximity), or the similarity of norms and values between emerging niches and incumbent local institutions (institutional proximity).

In summary, the DUET framework draws attention to the interactions of three critical dimensions (socio-technical experimentation, urban political processes, and sociospatial (re)configurations) to systematically analyze the complex interactions that shape urban energy transitions.

\section{Transition trajectories}

The temporal or multi-phase dimensions of urban energy transition constitute a critical point of analysis of systems of innovation. Ideas of pathways and trajectories have already had a strong bearing on the field (Foxon 2011; Geels and Schot 2007; Marletto 2014; McDowall 2014; Rydin et al. 2012; Rydin et al. 2013; Turnheim et al. 2015; Verbong and Geels 2010). Loorbach and Shiroyama (2016) noted the relevance and significance of the multi-phase perspective to deliver narratives of change and points of intervention to enable a transition. 
One way to examine the temporal trajectories of transition is to investigate the phases of technological innovations that show variation in terms of the maturity level of the technology and the degree of market uptake. Empirical evidence has shown that actual transitions do not take place following prescribed trajectories (Bulkeley et al. 2010) and that, instead, transitions are chaotic processes during which avoiding the foreclosure of alternative possibilities for low carbon development is more critical than ensuring clarity about the actual pathway to be followed (Rydin et al. 2013). However, defining an idealized trajectory enables the identification of parameters of comparison between urban contexts where similar processes are occurring at different moments in time. The multi-phase perspective identifies five phases in a typical transition trajectory: predevelopment, take-off, breakthrough, acceleration, and stabilization (Loorbach and Shiroyama 2016). Making a distinction between the phases of technological innovation is of scholarly and policy importance. Different phases could be interrelated; however, they are also distinctive in at least three aspects that have policy implications: (1) technological maturity and the scale of market uptake (Kim and Kim 2015; Sun and Nie 2015); (2) cost-effectiveness (Ellabban et al. 2014; Hagerman et al. 2016); and (3) stakeholders' responses from public, private and civil society sectors (Zhang et al. 2016). The five phases and associated features which are relevant in the analysis of energy transitions in China are highlighted in Table 1.

\section{Analytical framework}

Figure 1 provides a summary of the framework used for the analysis of the case studies. It integrates the spatial and multi-phase dimensions of urban energy transitions and enriches our theoretical understanding of how and why, and the extent to which these transitions occur. The focus is first, on the trajectory of change. A city may have gone through any of 1 to 5 of the multi-phase stages, perhaps following them in a linear trajectory or through different circular movements across phases. At any given moment, a city will have a particular 'DUET configuration,' that is, the arrangement among the processes of experimentation, politics, and socio-spatial factors that influence urban transitions. While urban areas do not follow linear trajectories from predevelopment to stabilization, the phase model enables a staged diagnose of specific moments in transition. The five phases are idealized stages that enable an understanding of the type of transformative effects of a given DUET configuration. Analyzing the DUET configuration with the multi-phased model enables an investigation of the relationship between the configurations of urban processes and the dynamics of system changes over time.

The framework delivers two contributions to the literature. First, the framework focuses on how and why energy transitions occur in the observed ways by focusing on the sociospatial interactional processes as both preconditions as well as outcomes of transitions, and by considering that the transitional processes may also reshape urban forms and settings. Second, the temporal dimension brings an evaluative element to our framework to study the extent to which there is an energy transition, particularly relevant for the case studies.

\section{Methodology}

This study adopts a comparative case study approach. Following the requirements of the DUET framework, each case study involves one city. Rather than defining the cities 
Table 1 The progression of five phases of technological transitions with feature description (adapted from IEA 2015; Kemp and Rotmans 2005; Kivimaa et al. 2019; Loorbach and Shiroyama 2016; Rotmans et al. 2001)

\begin{tabular}{|c|c|c|c|c|}
\hline \multirow[t]{2}{*}{ Phases } & \multirow[t]{2}{*}{ Definition } & \multicolumn{3}{|l|}{ Feature description } \\
\hline & & $\begin{array}{l}\text { Technology maturity } \\
\text { and the scale of market } \\
\text { uptake }\end{array}$ & Cost-effectiveness & Stakeholder attitude \\
\hline Predevelopment & $\begin{array}{l}\text { A dynamic equilibrium } \\
\text { where the status quo } \\
\text { does not visibly } \\
\text { change, but } \\
\text { experimentation takes } \\
\text { place. }\end{array}$ & $\begin{array}{l}\text { Basic R\&D; prototype; } \\
\text { demonstration projects; } \\
\text { patent development }\end{array}$ & $\begin{array}{l}\text { - Costs remain } \\
\text { high }\end{array}$ & $\begin{array}{l}\text { - Initial expert } \\
\text { interest in } \\
\text { technology }\end{array}$ \\
\hline Take-off & $\begin{array}{l}\text { The process of change } \\
\text { gets underway and } \\
\text { the state of the } \\
\text { system begins to shift. }\end{array}$ & $\begin{array}{l}\text { - Applied R\&D - } \\
\text { focusing on cost } \\
\text { reduction and } \\
\text { technology performance }\end{array}$ & $\begin{array}{l}\text { - Technology is } \\
\text { feasible but high- } \\
\text { cost gap }\end{array}$ & $\begin{array}{l}\text { - Growing expert } \\
\text { interest in } \\
\text { technology }\end{array}$ \\
\hline Breakthrough & $\begin{array}{l}\text { Novel niches start to } \\
\text { build up. }\end{array}$ & $\begin{array}{l}\text { - Applied R\&D - } \\
\text { emergence of business } \\
\text { models; small } \\
\text { companies } \\
\text { - Emergence of a niche } \\
\text { market }\end{array}$ & $\begin{array}{l}\text { - High-cost gap } \\
\text { remains, but } \\
\text { achieve cost- } \\
\text { effectiveness } \\
\text { under specific } \\
\text { conditions }\end{array}$ & $\begin{array}{l}\text { - Initial public } \\
\text { interest }\end{array}$ \\
\hline Acceleration & $\begin{array}{l}\text { Changes further speed } \\
\text { up, with structural } \\
\text { changes taking place } \\
\text { in a visible way. }\end{array}$ & $\begin{array}{l}\text { - Technologies still } \\
\text { under-utilized. Some } \\
\text { non-economic barriers, } \\
\text { such as social and insti- } \\
\text { tutional ones, stall their } \\
\text { uptake } \\
\text { - Market remains a } \\
\text { minor share } \\
\text { - Diverse and rapid } \\
\text { growth of new business } \\
\text { models which are more } \\
\text { customer-oriented }\end{array}$ & $\begin{array}{l}\text { - Technologies } \\
\text { are progressively } \\
\text { approaching } \\
\text { widespread cost- } \\
\text { competitiveness } \\
\text { - Rapid pace of } \\
\text { cost reduction } \\
\text { due to market } \\
\text { expansion and } \\
\text { penetration }\end{array}$ & $\begin{array}{l}\text { - Increasing } \\
\text { acceptance by } \\
\text { utilities and } \\
\text { communities }\end{array}$ \\
\hline Stabilization & $\begin{array}{l}\text { The speed of social } \\
\text { change decreases and } \\
\text { a new dynamic } \\
\text { equilibrium is reached. }\end{array}$ & $\begin{array}{l}\text { - Technology is mature } \\
\text { - Margin increase in } \\
\text { market uptake; new } \\
\text { installations slow down; } \\
\text { any new increases may } \\
\text { be additional or } \\
\text { replacement } \\
\text { - Mass-market exists; } \\
\text { the supply chain is well } \\
\text { established; consolida- } \\
\text { tion of the industry } \\
\text { structure }\end{array}$ & $\begin{array}{l}\text { - Cost-effective } \\
\text { gains due to } \\
\text { economies of } \\
\text { scale }\end{array}$ & $\begin{array}{l}\text { - Technology } \\
\text { becomes a part of } \\
\text { people's daily lives } \\
\text { (integration) } \\
\text { - Market and } \\
\text { regulatory } \\
\text { frameworks already } \\
\text { adapted to the } \\
\text { characteristics of the } \\
\text { technology } \\
\text { - Declining policy } \\
\text { support }\end{array}$ \\
\hline
\end{tabular}

spatially (i.e., with reference to an administrative boundary), each case comprises a bundle of socio-technical elements united by a shared narrative of urban development.

Case selection followed two criteria. First, we looked for cities where there is a distinguishable trend of acceleration towards the adoption of solar technologies. Second, we focused on different models of innovation to represent multiple transition pathways.

The first case, Foshan, is an example of a transition mediated by photovoltaic technologies. Transition actors in Foshan have actively engaged in developing new business models for distributed household PV systems. Currently, household solar represents $92 \%$ of solar projects in this city. The second case, Wuxi, shows how solar transitions relate to urban development strategies. In Wuxi, solar technologies, especially solar water heaters, have become tools to consolidate eco-city projects. The case of Rizhao, shows how the co-evolution of everyday practices and large-scale industrial 


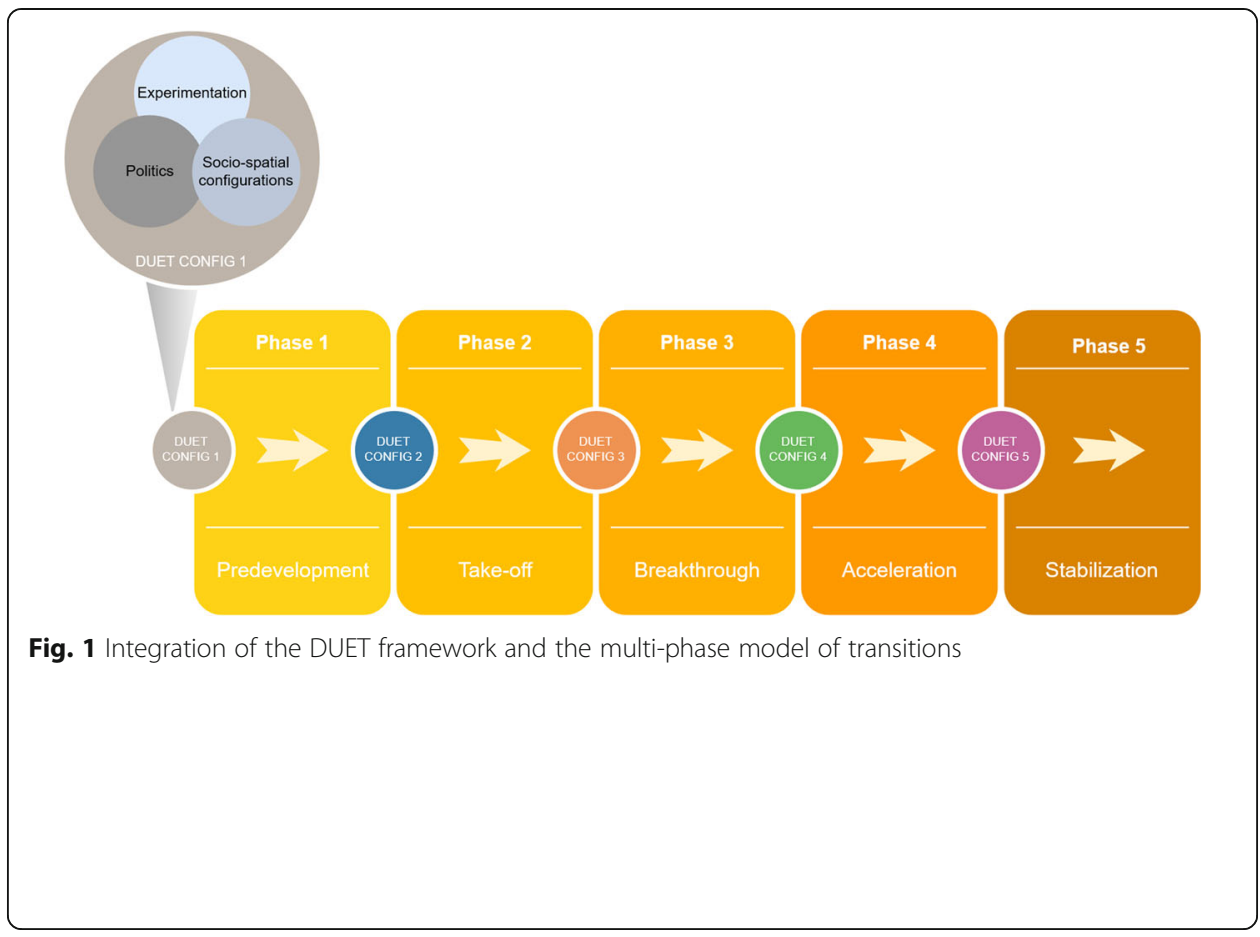

developments supported the expansion of low-cost water heating systems in all types of buildings. In this case, we took advantage of the previous application of the DUET framework to the case of Rizhao (see for instance, Huang et al. 2018a, 2018b), deepening the analysis with the use of new empirical materials to analyze the transition using a spatiotemporal perspective. Figure 2 shows the location of the three cities. A summary of the cities' characteristics is provided in Table 2.

Foshan is a city on the southeast coast that experienced a boom of household solar PV projects in 2016. With almost 1500 annual sunny hours, solar PV in Foshan has moderate solar resources. The city can harness approximately 1000 to 1200 annual full load hours (Foshan Statistics Bureau 2017). By the end of 2016, Foshan had 825 solar PV installations with a total installed capacity of $270 \mathrm{MW}$, which represented $0.3 \%$ of Foshan's total electricity consumption (Interview, $\mathrm{FS}^{1}{ }^{1}$ ). Although solar has remained a niche energy source, the exponential growth of household solar in Foshan in 2016 was noticeable. Solar houses in Foshan grew from 67 to 763 in less than 12 months, from early 2016 to the end of 2016.

Wuxi is a significant economic growth pole in the Yangtze River Delta region. Since entering the twentieth century, the city has delivered decarbonization measures. According to the Wuxi Statistics Bureau, the energy intensity in Wuxi has decreased by two-thirds during the recent decade, from 10.9 SCE/Yuan in 2004 to $4.1 \mathrm{SCE} / Y$ uan in 2015. One explanation is the growth of geothermal power and solar power in the industrial sector. Wuxi Taihu New Town is a 'national demonstration zone of lowcarbon eco-cities ${ }^{21}$ to promote the residential use of solar energy since 2009.

Rizhao city is a model of the adoption of solar water heaters (SWHs). Since 2007, most of its 650,000 population downtown use SWH. ${ }^{3}$ In June 2007, Rizhao was

${ }^{1}$ Notation follows the coding guide presented in Table 4 in Appendix 1. 


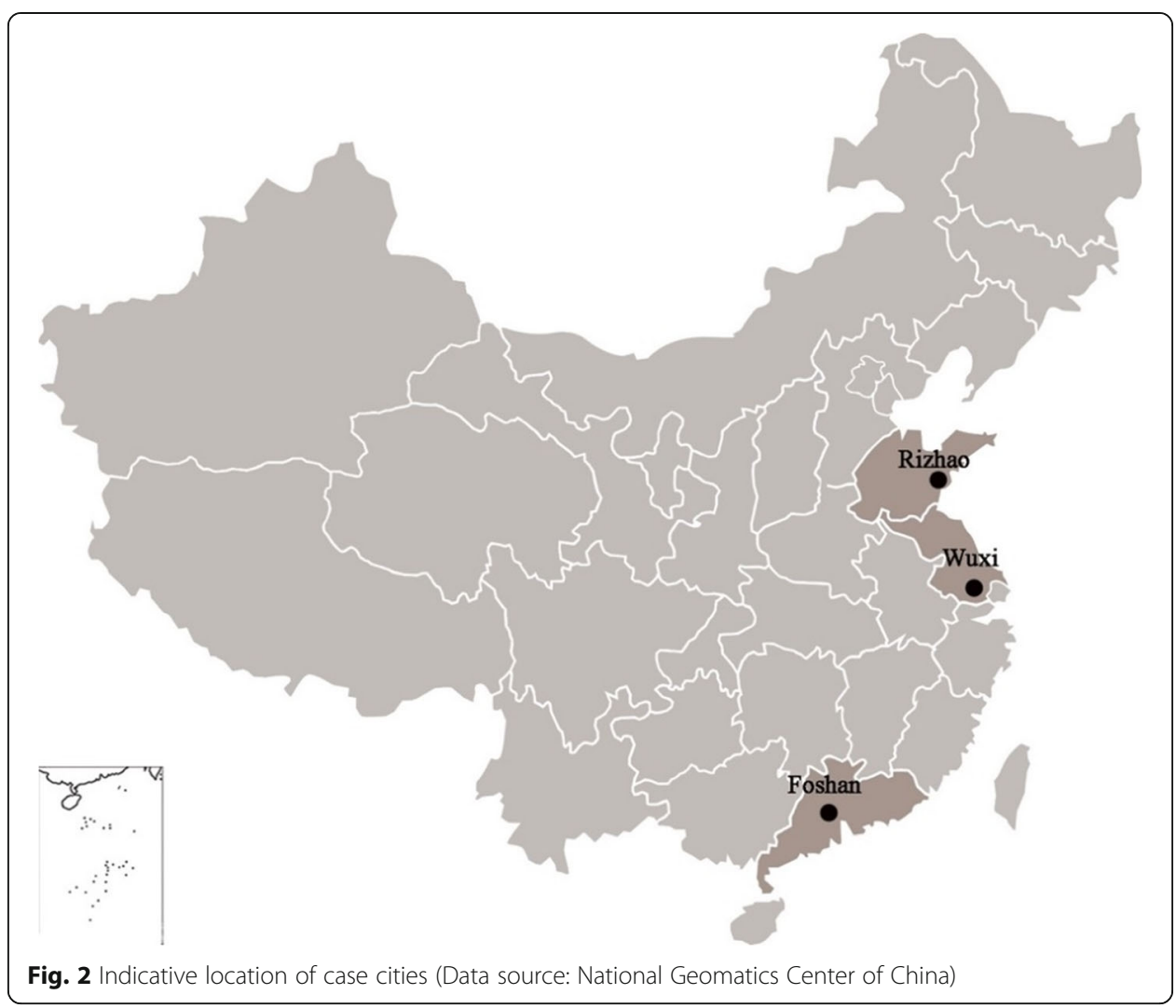

Table 2 Background information for Foshan, Rizhao, and Wuxi (all data compiled from the National Bureau of Statistics of China, except where indicated)

\begin{tabular}{|c|c|c|c|c|}
\hline & & Foshan & Rizhao & Wuxi \\
\hline \multirow{7}{*}{$\begin{array}{l}\text { Basic } \\
\text { characteristics } \\
(2016)\end{array}$} & Location & Southeast; coastal & Northeast; coastal & East; coastal-inland \\
\hline & Administrative status & $\begin{array}{l}\text { Prefecture-level } \\
\text { city }\end{array}$ & Prefecture-level city & Prefecture-level city \\
\hline & Province & Guangdong & Shandong & Jiangsu \\
\hline & GDP (billion yuan) & 801.0 & 180.2 & 921 \\
\hline & Population (million) & 7.43 & 2.99 & 6.53 \\
\hline & Area $\left(\mathrm{km}^{2}\right)$ & 3797 & 5358 & 4627 \\
\hline & Solar energy potential ${ }^{a}$ & $\begin{array}{l}\text { In "solar-rich" } \\
\text { category } \\
\text { (Category III) }\end{array}$ & $\begin{array}{l}\text { In "solar-rich" category } \\
\text { (Category III) }\end{array}$ & $\begin{array}{l}\text { In "solar-rich" category } \\
\text { (Category III) }\end{array}$ \\
\hline \multicolumn{2}{|c|}{ Main drivers of solar innovation } & $\begin{array}{l}\text { A boom in } \\
\text { household PV } \\
\text { installations }\end{array}$ & $\begin{array}{l}\text { Co-evolution of solar } \\
\text { technology and urban } \\
\text { planning }\end{array}$ & $\begin{array}{l}\text { Adjustment of industrial } \\
\text { policy to household } \\
\text { practices }\end{array}$ \\
\hline \multirow[t]{3}{*}{$\begin{array}{l}\text { Energy profile } \\
(2016)^{\mathrm{b}}\end{array}$} & $\begin{array}{l}\text { Total energy consumption (10, } \\
000 \text { tons of standard coal } \\
\text { equivalent) }\end{array}$ & 1740 & 2694 & $3800^{c}$ \\
\hline & Coal consumption $(10,000$ tons) & 1088 & 1115 & 2559 \\
\hline & $\begin{array}{l}\text { Electricity consumption (100 } \\
\text { million } k W h \text { ) }\end{array}$ & 287.4 & 177.0 & 638.7 \\
\hline
\end{tabular}

a http://www.nea.gov.cn/2014-08/03/c_133617073.htm;

National Research Council. (2011). The power of renewables: opportunities and challenges for China and the United States. National Academies Press. (page. 45)

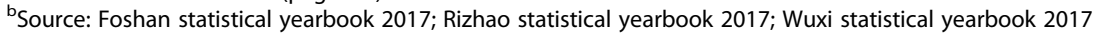

'This figure of Wuxi is for the year of 2015 
awarded the World Clean Energy Award by the United Nations (UN) for its outstanding achievements in the application of solar energy. With an increasing proportion of medium- and high-rise buildings in urban areas, the Rizhao municipal government enacted a regulation that required the mandatory installation of SWHs in newly built buildings. By 2014, the popularization rate of SWHs in Rizhao's urban areas was above $90 \%$, and the total solar collecting area reached more than 1.2 million $\mathrm{m}^{2}$.

The case studies were compiled using both the secondary literature and semistructured interviews. Interviews explored different aspects of the urban energy transition, examining processes of experimentation, urban politics, and socio-spatial factors. The secondary literature was used to build a timeline to help describe each city's trajectory, and contrasting the information from the interviews.

In total, we conducted 58 interviews, 11 in Foshan, 27 in Rizhao, and 20 in Wuxi (Table 4 in Appendix). The interviews, which lasted from 30 to $170 \mathrm{~min}$, were conducted in the local language. After transcription, the interviews were analyzed in two stages. First, they were used to create a temporal narrative of the transition in each city following the multi-phase model. Second, they were coded following the dimensions of the DUET framework to explain changes in each trajectory. Each case was analyzed by two different members of the team, and cases were then presented and discussed among the whole team.

\section{Local variations of urban energy transitions in the three cities}

Results consist of a historical analysis of the three dimensions of transitions dynamics (experimentation, urban politics and socio-spatial configurations) and a detailed discussion on the factors that drive the urban transition trajectories of each city, in line with the analytical framework.

\section{Dimensions of urban transitions in the three cities}

\section{Experimentation}

The emergence and growth of socio-technical niche experimentation of the three cases show that there are varied dynamics of innovation at work.

In Foshan, the Sanshui Industrial Park (a national-level High-tech Development Zone) is a critical PV manufacturing cluster locally and regionally (interview, FS4 and FS5). In 2011, the Park produced 70\% of PV cells installed in Guangdong province. The provincial government has designated the Sanshui Industrial Park as a strategic manufacturing base for solar PV, and the Park has a national designation as a distributed solar PV demonstration zone in 2013 (Guangdong DRC 2014; NEA 2014; People's Government of Sanshui 2014). The Park is home to some well-known solar PV companies (e.g., Aikosolar, Powerway, Guangdong NRE Technology, Guangcheng Aluminum). Their operations have strong political support. For instance, programs such as the national solar FIT and the Guangdong Solar PV Power Generational Development Plan were introduced in 2014 (interview FS1). The municipal government's solar policy also introduced a FIT of RMB 0.15/kWh (based on generation, 3 years) and a direct subsidy (RMB $1 / \mathrm{W})$ on installed capacity (interview, FS1 and FS4). The Sanshui Industrial Park

\footnotetext{
${ }^{2}$ Since 2009, Taihu New Town has been planned as a demonstration project from the national eco-cities policy agenda of the Ministry of Housing and Urban-Rural Development

${ }^{3}$ http://www.cleanenergyawards.com/fileadmin/redaktion/factsheets/factsheet_webversion_6.pdf
} 
also enjoys investment and policy benefits as a national-level high-tech development zone (interview, FS1 and FS4). Some village committees have shown leadership to become "solar villages" by piloting solar PV demonstration projects (interview, FS8 and FS9). Capitalizing on the emerging niche market, market agents, particularly private solar installers, have developed new business models to create economic value for new solar products and services (interview, FS8 and FS9). State-affiliated banks and insurance companies provide PV loans and insurance with the support of the Foshan government (interview, FS8 and FS9).

In Wuxi, we observe vigorous entrepreneurial activities in the development of SWHs. By the year 2016, over 100 core solar enterprises had clustered in Wuxi, among which Leiyu solar Co., Ltd., Sun-tech Power Holdings Co., Ltd., and Wankang Solar Water Heater Co. Ltd., played leading roles in the global market (interview, WX2). For example, Sun-tech, founded in 2001 with the support of $\$ 6$ million investment from local state-owned enterprises and government, had its initial public offerings on the New York Stock Exchange in 2005 and became the biggest PV module supplier in the world in 2011. With Suntech's fast growth, many affiliated enterprises and suppliers have been established in Wuxi forming a solar power industry cluster. Wankang, as a new technology enterprise, has established a large-scale base to produce about 250,000 sets of solar heaters every year (interview, WX10). These local companies made public campaigns and established national research centers for solar energy technology innovation. Since 2009, the city of Wuxi began to annually host the Chinese Renewable Energy Conference and product exhibitions, which were highly influential events embraced by politicians, planners, technicians, suppliers, and market buyers. These events led to the booming of local business opportunities and the establishment of SWH legitimacy. In 2016, the roof area with installed SWHs and distributive PV stations in Taihu was over $1.6 \mathrm{~km}^{2}$ (interview, WX12).

Niche experimentation with water-in-glass evacuated tube SWHs in Rizhao shows innovation driven by unmet social needs. There is a long tradition of citizen-led technological experimentation in Rizhao. For example, in the 1980s, residents put "solar water bags" on the rooftops to absorb solar energy for water heating. Bags were eventually replaced by more durable materials such as iron tanks, an embryonic form of integral passive SWHs (interview, RZ16 and RZ17). Linyi city's wholesale market became well-known for selling SWH parts and accessories in Shandong. At the time, residents and self-employed entrepreneurs purchased SWH accessories and assembled them by themselves (interview, RZ5 and RZ6). In 1984, Professor Zhiqiang Yin at Tsinghua University developed the technology to produce SWHs with evacuated glass tubes (interview, RZ14). It was not until the late 1990s when industrial enterprises such as Himin (founded in 1996) started to produce complete machines at a large scale that the market for SWHs was opened up and expanded rapidly. After that, entrepreneurs actively mobilized resources, in terms of diffusing knowledge, attracting investment, and creating legitimacy (Huang et al. 2018b). In the early 1990s, the mayor supported the local solar panel industry by providing subsidies to firms engaged in solar technology research to encourage the continued expansion of the sector (interview, RZ4), which eventually led to an integral SWH policy in 2004. In 2003, a local SWH manufacturer that specializes in wall-mounted flat plate SWHs, which are better suited for high-rise buildings, was founded in Rizhao (interview, RZ7 and RZ8). 


\section{Urban politics}

The interviewees were keen to highlight examples that show the alignment of national agendas, urban priorities, business interests, and household incentives. Differing motivations of governments (at the national, provincial, and city levels), market agents (including grid companies and solar installers), and households eventually converged to support solar technologies. In each case, solar technologies have constituted a response to context-specific environmental politics.

In Foshan, the alignment of diverse economic and regulatory interests strengthened the legitimacy of solar PV. Solar PV emerges as a suitable response to current constraints to industrial development (interview, FS8). In Foshan, industrial policies tend to support less-polluting industries at the expense of traditional manufacturing sectors (interview, FS1 and FS8). As air pollution and contaminants have become a cause for concern among the rising middle class in Foshan, the local government has made active efforts to deliver and enforce environmental policies (interview FS2 and FS8). Conflicts have emerged in the industrial landscape. In 2017, for example, TetraPack closed a factory that had operated in Foshan for 26 years, relocating the production to other plants in Jiangsu province, the Inner Mongolia autonomous region, and Beijing (Zhu 2017).

In Foshan, the solar industry has provided an alternative model of industrial growth that fits national development priorities and local environmental concerns. The central government has prioritized solar PV as one of the energy options to promote industrial growth, alleviate national poverty, mitigate climate impacts, and enhance national energy security (interview, FS1, FS4 and FS5). Local support for distributed PV grew after the establishment of renewable targets at the national level. Grid companies and their local subsidiaries in Foshan since then have provided enhanced services to connect PV systems to the grid (interview, FS1 and FS2). A local power grid company also set up 'a solar PV counter' to streamline grid-connection permitting procedures for PV owners (interview FS2). Urban policy changes have subsequently followed. The municipal government, for example, supported the establishment of a PV manufacturing cluster in Sanshui Industrial Park and framed solar PV as a driver for regional industrial growth (interview, FS4 and FS5).

In Wuxi, the development of SWH technologies has been linked to political crises. In 2007, a blue algae outbreak in Taihu Lake, a lake in the center of the city, posed an environmental and public health crisis that reverberated throughout the city and triggered political support for the development of clean energy (Chen et al. 2009). In 2008, the municipal government required the mandatory installation of SWHs in all new housing buildings under 12 floors. The municipal government also took responsibility for the installation of SWHs in public buildings, including hotels and commercial-residential buildings. Government-built affordable housing and relocation housing also have mandatory SWHs (interview, WX1, WX4,WX5, WX6 and WX13). In 2009, Party Secretary Yang Weize stated at a clean-tech symposium in Stockholm that "The Taihu Lake Blue Algae outbreak two years ago taught us a good lesson. (...) Thus we like to shift from the traditional metallurgical and mechanical industries to more environmentally friendly industries as we encounter the environmental problems now." The municipal government has engaged in the delivery of Wuxi's image as a leading clean-tech industry node. The portfolio of policy measures to support clean-tech in Wuxi includes preferential taxes, improved legal services, reduced business fees, technology 
consultancy services, and improvement of the financing service system (Oberheitmann 2012). From 2010, Wuxi implemented a ' 4610 plan' (four policies to accelerate 6 technologies in 10 demonstration projects), which established a 'building energy-saving fund' to support the installation costs of solar technologies (interview, WX3, WX5 and WX7). The municipal government has also established a special fund for low carbon projects, with specific support for PV (Philipps et al. 2012).

Moreover, the development of the solar PV industry in Wuxi is part of the city's wider economic restructuring in response to national policies of encouraging lowcarbon high-tech industries. The municipal government has established international partnerships to showcase Wuxi as a global example of a low-carbon city. Partnerships include, for example, cooperation with the Swedish Government to build a low carbon eco-city (Yin et al. 2016) and with the German foundation Stiftung Mercator on the 'Low Carbon Future Cities' project (Dienst et al. 2013).

In Rizhao, the municipal government's actions have been directed towards harnessing citizen-led initiatives to develop the local industry. In 2007, the municipal government enacted the mandatory installation regulation of SWHs in newly built low-rise and multistory residential buildings. ${ }^{4}$ In response to intensified promotion of clean energy sources at both the national and provincial levels, the Rizhao municipal government extended the mandatory installation regulation of SWHs to high-rise buildings in 2010 (Huang et al. 2018a; Westman et al. 2019). This regulation granted political legitimacy to SWH products. The SWH industry then witnessed a renewed wave of prosperity and the opening up of a new market segment in construction projects (interview, RZ5 and RZ6). The Rizhao case study is also an example of the power of low carbon agendas to shape political careers. After the campaign, local officials explained that the mayor responsible for initiating the scheme gained credit as both a politician and a policy entrepreneur (interview, RZ4).

Overall, the three cases point towards the role of the municipal government in forging alignment between existing economic and industrial interests and the new emerging interests associated with the solar industry. In every city, a change in local environmental politics has motivated the adoption of the technology, whether by seeking new opportunities for development in a highly polluted city (Foshan), the constitution of the city as a low carbon exemplar (Wuxi), or the harnessing of citizen-led initiatives for large-scale industrial development (Rizhao). Every case study shows that economic development priorities and the strengthening of industry-municipal government alliances determined the development of solar innovations and the spread of the technology. At the same time, broader political interests and active processes of contestation- particularly from any actors outside the industrial-government complex- remain invisible.

\section{Socio-spatial factors}

Foshan is situated beside significant manufacturing hubs such as Guangzhou and Dongguan. Locally, Foshan is also home to the Sanshui Industrial Park and its solar PV manufacturing cluster and pilot demonstrator. Foshan has traditionally boasted an entrepreneurship culture (interview, FS2, FS8 and FS9). Approximately 95\% of all 
Foshan businesses are small-to-medium enterprises. Foshan citizens have also been willing to accept feed-in-tariffs generally (interview, FS2). In this context, the solar PV industry has emerged in Foshan alongside innovative business models that provide new services and generate co-benefits, including the use of solar PV for retirement savings, PV loans, and PV-related insurance. The proximity between the financial industry and the solar PV industry has fostered the development of mutually beneficial institutional innovations. Nevertheless, these examples are only illustrative as the solar industry in Foshan is still emerging.

Solar PV technologies have spread through governance structures in urban villages. Urban villages have committees that operate as quasi-government actors. They have provided protected spaces for both niche experimentation and local networks to spread the use of solar PV. For example, the local leaders in Luonan Village, in Central Foshan, recently installed a $32.76 \mathrm{~kW}$ solar PV demonstration project on their villagers' committee building (interview, FS9). The project is an example of self-regulation, in which the communities themselves provide spaces to display the latest solar technologies in situ. The proximity between individuals invested in both the villages and the solar industry enables the creation of such spaces. For example, in Luonan Village, an initiator was an employee at the Southern Power Grid (a national grid company of China owned by the central government) with a personal connection to the village. A solar distributor and installer interviewed in Foshan detailed how he mobilized family relationships to raise interest in solar technologies (interview, FS9).

Similarly, Wuxi's positioning as a solar tech hub builds on a strong foundation of manufacturing and technology development capacity (interview, WX3 and WX8). The city has a long history of functioning as a hub of industrial development. As early as the 1930s, the establishment of a silk mill in the urban area contributed to the emergence of one of the country's first large industrial urban agglomerations, and the city eventually became a center for metal smelting, electrical equipment processing, and manufacturing, chemical industries and textiles (Philipps et al. 2012). Moreover, Wuxi is located at the center of Yangtze River Delta, with good access to around forty universities and research institutes in Shanghai, Jiangsu Province and Zhejiang Province. The municipal government has actively encouraged information exchanges between academia and the private sector (Philipps et al. 2012). The positioning of Wuxi as an international leader in the development of solar technology is most often explained as a combination of industrial policy and access to global networks of capital and expertise (Wuxi Government, 2011). Local factors also stimulated the development of solar energy technology, particularly in the Taihu New Town (interview, WX12, WX19 and WX20). Eco-town discourses emerged alongside an increasing interest in 'greener' lifestyles, which residents now sought to enact in their everyday lives. After the construction of housing projects under a green science-tech label, building-integrated SWH technologies became the must-have eco-technology for middle-income homes and villas. For example, the real estate developer, Landsea, has actively engaged in the green residential property development business by using various green technologies in their green buildings, including the installation of solar water heater. One of the interviewed residents claimed his purchase of the green-certificated property was due to the financial saving incentive for the utility bill (interview, WX11). 
Socio-spatial factors have facilitated the expansion of SWHs in Rizhao. Many residents in Rizhao have developed an interest in SWHs since the 1980s (interview, RZ18, RZ24, and RZ25), further facilitated by proximity to an industry cluster of SWHs in Shandong province. Advanced technologies substituted improvised devices developed by residents. The symbolic significance of the idea of obtaining energy from the sun particularly fitted a city with a 'Sun Worship Culture,' something often mentioned in the interviews conducted in the city (see also Huang et al. 2018a). As explained by one interviewee (interview, RZ14):

"Rizhao's name ("日照") follows an old Chinese saying that it is the place illuminated by the first rays of the sun ("日出初光先照")... A lot of elements from the 'Sun Worship Culture' have been inscribed into the generic identity of Rizhao."

Citizens see the sun as an integral part of the city's identity, which contributes to an inherently positive view of solar energy systems. When local industries looked towards an endogenous market for solar energy, they found that SWHs had seamlessly been integrated into Rizhao's everyday life. The majority of citizens in Rizhao already used water-in-glass evacuated tube SWHs before the municipal government published supporting regulations in 2007. As indicated by one interviewee (interview, RZ27):

"I started to use the SWH around 1997. It was quite early... We all thought it was so convenient, and it was not expensive. We only needed to pay for the water."

Because SWHs were seamlessly integrated into everyday life, residents found no inconvenience in the use of SWHs. While in other cities the irregular provision of hot water may be seen as a problem, in Rizhao, residents do not question it (Huang et al. 2018b).

\section{Urban trajectories}

A combination of the DUET configuration with the multi-phased model enables an investigation of the relationship between the configurations of urban processes and the dynamics of system changes over time. On the one hand, the phase model provides a picture of to what extent have the three cities facilitated solar energy transitions; on the other hand, the three dimensions of the DUET framework offer insights into the dynamics that have driven the transition trajectories of the three cities (answering the how and why question).

In Foshan, political factors provided the impetus for the transition, with an overall demand by the city's government and its population to address the long-standing pollution problems stemming from its long history of industrial development. For instance, the designation of the Sanshui Industrial Park as a national demonstration zone for distributed solar PV and the introduction of programs such as the national solar FIT and the Guangdong Solar PV Power Generational Development Plan in 2014 facilitated resource mobilization, supported the proliferation of business, and generated a nascent interest in solar technologies, marking the entry into the breakthrough phase. Despite the popularity of solar PV technologies in urban villages, the actual spread of solar technologies still relies on isolated pioneers drawing on significant personal 
connections and expertise. Since 2016, Foshan has moved towards the acceleration phase. For example, the number of installed solar PV in Foshan went from less than a dozen in 2015 to 763 by the end of 2016 (interview, FS2, FS6 and FS7). Costs diminished rapidly. Payback periods were reduced from 15 to 8 years in the period from 2015 to 2016. Nevertheless, multiple elements from the previous phases remain, and there is as-yet little evidence of future consolidation (interview, FS1 and FS2). The potential for the solar sector relates to its potential to fill a new niche of acceptable industries, following the rise of environmental concerns in the political agenda.

In Wuxi, the drive towards solar technologies is part of a broader effort to constitute the city as an eco-city exemplar. The founding of Sun-tech in 2001 triggered the formation of a solar power industry in Wuxi, marking the breakthrough phase for solar transitions. Following health scares in the late 2000s, particularly the blue algae outbreak in Taihu Lake in 2007, Wuxi entered the acceleration phase for solar transitions, followed by a series of solar policies. The mandatory installation regulation of SWHs in 2008 and the '4610 plan' in 2010 played facilitating roles in solar transitions. Simultaneously, many small enterprises have merged into larger suppliers able to meet the rising demand. Since 2015, Wuxi has reached the stabilization phase, with the total solar power generation reaching $90 \mathrm{MW}$. SWHs have become lifestyle items and must-have technologies in newly built developments, constituting a ubiquitous part of Wuxi's energy landscapes (interview, WX8, WX9 and WX10).

In Rizhao, the coexistence of complementary but not exactly similar technologies complicates the phase analysis. For water-in-glass evacuated tube SWHs, a predevelopment stage emerged in the 1980s when grassroots groups experimented with the utilization of low-tech solar water heating systems (interview, RZ21, RZ22 and RZ23). In this case, public interest preceded, rather than followed, industrial innovation. The take-off stage could be dated to 1984, the year in which the technology to produce SWHs with evacuated glass tubes was developed. Since the late 1990s, the founding of leading enterprises such as Himin brought the technology to the breakthrough and acceleration stage. Mass production increased the cost-competitiveness and the market for SWHs was opened up and expanded rapidly. Rizhao already reached the stabilization phase in the early 2000s, with more than $70 \%$ of the urban households using SWHs. While for wall-mounted flat plate SWHs, the breakthrough phase could be dated to 2003, when a local SWH manufacturer specialized in wall-mounted flat plate SWHs was founded, marking the ability of mass production and costeffectiveness. The mandatory installation of building-integrated SWH in Rizhao has greatly accelerated the market expansion of wall-mounted flat plate SWHs, marking the entry in the acceleration phase. However, there is no evidence that this new SWH technology will ever reach a stabilization phase.

Overall, none of the cases followed neatly the different phases of innovation described in the literature. Nevertheless, features of different phases at various stages of the development of solar technologies exist for each case study, as summarized in Table 3. ${ }^{5}$ The analysis shows that within a similar innovation context, locally specific processes of experimentation, political dynamics, and socio-spatial factors have a defining influence on 
Table 3 A summary of the key events driving urban transition trajectories in Foshan, Wuxi, and Rizhao

\begin{tabular}{|c|c|c|c|}
\hline Cities & Phases & Key events & Outcome \\
\hline \multirow[t]{2}{*}{ Foshan } & Breakthrough & $\begin{array}{l}\text { - Sanshui Industrial Park was designated as a } \\
\text { national demonstration zone for distributed solar } \\
\text { PV in } 2013 \\
\text { - Introduction of the national solar FIT and the } \\
\text { Guangdong Solar PV Power Generational } \\
\text { Development Plan in } 2014 \\
\text { - The municipal government introduced a FIT of } \\
\text { RMB 0.15/kWh and a direct subsidy (RMB 1/W) } \\
\text { on installed capacity } \\
\text { - Village committees piloted solar projects in } \\
\text { urban villages } \\
\text { - Market agents developed new business models } \\
\text { for solar products and services }\end{array}$ & $\begin{array}{l}\text { - Emergence of new business } \\
\text { models } \\
\text { - Emergence of a niche market } \\
\text { - Cost gap narrowed due to } \\
\text { subsidies } \\
\text { - Initial public interest }\end{array}$ \\
\hline & Acceleration & $\begin{array}{l}\text { - The number of installed solar PV went from less } \\
\text { than a dozen in } 2015 \text { to } 763 \text { by the end of } 2016 \\
\text { - Payback periods were reduced from } 15 \text { to } 8 \\
\text { years in the period from } 2015 \text { to } 2016 \\
\text { - The proliferation of new business models } \\
\text { - Grid companies and their local subsidiaries in } \\
\text { Foshan provided enhanced services to connect } \\
\text { PV systems to the grid }\end{array}$ & $\begin{array}{l}\text { - Market expanding, but remains } \\
\text { a minor share } \\
\text { - Technologies approaching cost- } \\
\text { competitiveness } \\
\text { - Diverse and rapid growth of } \\
\text { business models } \\
\text { - Increasing acceptance by } \\
\text { utilities and communities }\end{array}$ \\
\hline \multirow[t]{3}{*}{ Wuxi } & Breakthrough & $\begin{array}{l}\text { - In 2001, Sun-tech was founded with the support } \\
\text { of local government. } \\
\text { - A solar power industry cluster started to form. }\end{array}$ & $\begin{array}{l}\text { - Emergence of business models } \\
\text { - Initial public interest }\end{array}$ \\
\hline & Acceleration & $\begin{array}{l}\text { - In 2007, the blue algae outbreak in Taihu Lake } \\
\text { posed an environmental and public health crisis } \\
\text { that reverberated throughout the city and } \\
\text { triggered political support for the development } \\
\text { of clean energy. } \\
\text { - In 2008, the municipal government required the } \\
\text { mandatory installation of SWHs in all new } \\
\text { housing buildings under } 12 \text { floors } \\
\text { - Wuxi Taihu New Town was designated as a } \\
\text { 'national demonstration zone of low-carbon eco- } \\
\text { cities' in } 2009 \\
\text { - From 2010, Wuxi implemented a ' } 4610 \text { ' plan } \\
\text { (four policies to accelerate } 6 \text { technologies in } 10 \\
\text { demonstration projects) }\end{array}$ & $\begin{array}{l}\text { - Market expansion due to policy } \\
\text { support, but remains a minor } \\
\text { share } \\
\text { - Increasing public interest }\end{array}$ \\
\hline & Stabilization & $\begin{array}{l}\text { - The total solar power generation reached } 90 \text { MW } \\
\text { in } 2015 \\
\text { - By the year 2016, over } 100 \text { core solar enterprises } \\
\text { had clustered in Wuxi } \\
\text { - In 2016, the roof area with installed SWHs and } \\
\text { distributive PV stations in Taihu was over } 1.6 \mathrm{~km}^{2}\end{array}$ & $\begin{array}{l}\text { - Mass market exists } \\
\text { - The supply chain is well } \\
\text { established } \\
\text { - Consolidation of the industry } \\
\text { structure } \\
\text { - Increasing interest in 'greener' } \\
\text { lifestyles }\end{array}$ \\
\hline \multirow[t]{4}{*}{ Rizhao } & Predevelopment & $\begin{array}{l}\text { - The emergence of sporadic grassroots } \\
\text { experiments in early 1980s due to social needs }\end{array}$ & $\begin{array}{l}\text { - Costs remain high due to lack } \\
\text { of economies of scale } \\
\text { - Initial expert interests }\end{array}$ \\
\hline & Take-off & $\begin{array}{l}\text { - The technology to produce SWHs with } \\
\text { evacuated glass tubes was developed in } 1984\end{array}$ & $\begin{array}{l}\text { - Technology is feasible but } \\
\text { high-cost gap remains } \\
\text { - Growing expert interest in } \\
\text { technology }\end{array}$ \\
\hline & $\begin{array}{l}\text { Breakthrough \& } \\
\text { Acceleration }\end{array}$ & $\begin{array}{l}\text { - In the early 1990s, subsidies were provided to } \\
\text { local solar firms } \\
\text { - Leading enterprises started to produce complete } \\
\text { machines of water-in-glass evacuated tube SWHs } \\
\text { at a large scale in late 1990s }\end{array}$ & $\begin{array}{l}\text { - Emergence of new business } \\
\text { models and companies } \\
\text { - Technologies are progressively } \\
\text { approaching cost- } \\
\text { competitiveness } \\
\text { - Rapid pace of cost reduction } \\
\text { due to market expansion and } \\
\text { penetration } \\
\text { - Increasing acceptance by } \\
\text { utilities and communities }\end{array}$ \\
\hline & Stabilization & - Till the early 2000 s, more than $70 \%$ of the urban & - Technology is mature \\
\hline
\end{tabular}


Table 3 A summary of the key events driving urban transition trajectories in Foshan, Wuxi, and Rizhao (Continued)

\begin{tabular}{|c|c|c|c|}
\hline Cities & Phases & Key events & Outcome \\
\hline & & $\begin{array}{l}\text { households using water-in-glass evacuated tube } \\
\text { SWHs } \\
\text { - The introduction of the mandatory installation of } \\
\text { SWHs in } 2007 \\
\text { - The extension of the mandatory installation of } \\
\text { SWHs to high-rise buildings in } 2010\end{array}$ & $\begin{array}{l}\text { - Mass market exists } \\
\text { - Cost-effective due to econ- } \\
\text { omies of scale } \\
\text { - Widespread acceptance by } \\
\text { communities } \\
\text { - Technology becomes a part of } \\
\text { people's daily lives }\end{array}$ \\
\hline
\end{tabular}

the possibilities for a transition and its consequences. The comparative analysis suggests that the close alliance between municipal governments and the solar industry is a crucial factor shaping urban energy transitions in China.

\section{Conclusion}

Rather than a single, centrally-led urban energy transition, the comparative analysis shows that China is undergoing multiple urban energy transitions shaped by the close alliance between municipal governments and the solar industry. The increasing interest in transition pathways, rather than trajectories (Foxon 2011; Rydin et al. 2012; Rydin et al. 2013; Turnheim et al. 2015; Verbong and Geels 2010), points towards understanding multiplicity as a central condition of urban energy transitions. The integration of the multi-phased model analysis and the DUET framework is a means to explore this complexity. The three case studies here show that thinking in terms of phases is a useful means to diagnose specific moments in transition as long as the transition is not understood as a strictly linear process.

The systematic application of the two frameworks enables a detailed description of place-specific heterogeneous transitions. While both Wuxi and Rizhao have managed to reach the stabilization stage of solar transitions, Foshan is still going through the acceleration phase, with the potential for further market expansion and socio-spatial integration. The analysis highlights the unexpected moments in the dynamics of transition. Alliances between the industry and the municipal government were instrumental in every case. However, their role was very different in each city. In Foshan, the solar industry offered a pathway for industrial transformation in a highly polluted city, and the government supported experimentation in both industrial parks and urban communities. In Wuxi, the rise of environmental concerns in both national and local political agendas has had a direct impact on the context of innovation, and the development of the solar sector aligns with the strategy of delivering the city as an eco-city exemplar. In Rizhao, the spread of solar water heaters builds on a long history of citizen-led experimentation and the seamless integration of SWHs into everyday life. The alliance between the municipal government and the nascent solar industry sought to harness an existing social trend. In sum, the results highlight the importance of engaging with place-specific analysis of urban energy transitions (Coenen and Truffer 2012).

This place-based analysis is also needed to avoid common misconceptions about urban transitions. National government support can accelerate the uptake of specific

\footnotetext{
${ }^{5}$ Because the trajectory of wall-mounted flat plate SWH technology is fragmented, Table 3 only presents the trajectory of water-in-glass evacuated tube SWHs in Rizhao
} 


\section{Appendix}

Table 4 List of interviews

\begin{tabular}{|c|c|c|c|c|c|c|}
\hline Actor type & $\begin{array}{l}\text { Number of } \\
\text { Interviewees }\end{array}$ & Affiliation of interviewees & $\begin{array}{l}\text { Interview } \\
\text { date }\end{array}$ & $\begin{array}{l}\text { Interview } \\
\text { duration }\end{array}$ & $\begin{array}{l}\text { Interview } \\
\text { location }\end{array}$ & Coding \\
\hline \multicolumn{7}{|l|}{ Rizhao } \\
\hline \multirow[t]{4}{*}{ Government } & \multirow[t]{4}{*}{4} & $\begin{array}{l}\text { Bureau of Development and } \\
\text { Reform in Ju county, Rizhao }\end{array}$ & $\begin{array}{l}14 / 10 / \\
2016\end{array}$ & 122 mins & $\begin{array}{l}\text { Haihui Group's } \\
\text { office building }\end{array}$ & $\begin{array}{l}\text { RZ1 } \\
\text { and } \\
\text { RZ2 }\end{array}$ \\
\hline & & $\begin{array}{l}\text { Bureau of Housing and } \\
\text { Urban-Rural Development in } \\
\text { Ju county, Rizhao }\end{array}$ & $\begin{array}{l}17 / 10 / \\
2016\end{array}$ & 73 mins & $\begin{array}{l}\text { People's } \\
\text { commune } \\
\text { restaurant }\end{array}$ & RZ3 \\
\hline & & \multirow{2}{*}{$\begin{array}{l}\text { Bureau of Housing and } \\
\text { Urban-Rural Development in } \\
\text { Rizhao }\end{array}$} & $\begin{array}{l}19 / 10 / \\
2016\end{array}$ & 67 mins & $\begin{array}{l}\text { Rizhao Renjia } \\
\text { restaurant }\end{array}$ & \multirow[t]{2}{*}{ RZ4 } \\
\hline & & & $\begin{array}{l}21 / 10 / \\
2016\end{array}$ & 41 mins & The official's car & \\
\hline \multirow[t]{3}{*}{ Manufacturer } & \multirow[t]{3}{*}{7} & Kehao & $\begin{array}{l}13 / 10 / \\
2016\end{array}$ & 23 mins & $\begin{array}{l}\text { Kehao's office } \\
\text { building }\end{array}$ & $\begin{array}{l}\text { RZ5 } \\
\text { and } \\
\text { RZ6 }\end{array}$ \\
\hline & & Muyang & $\begin{array}{l}14 / 10 / \\
2016\end{array}$ & 30 mins & $\begin{array}{l}\text { Muyang's office } \\
\text { building }\end{array}$ & $\begin{array}{l}\text { RZ7 } \\
\text { and } \\
\text { RZ8 }\end{array}$ \\
\hline & & Himin & $\begin{array}{l}25 / 10 / \\
2016\end{array}$ & 128 mins & $\begin{array}{l}\text { Himin's office } \\
\text { building }\end{array}$ & $\begin{array}{l}\text { RZ9, } \\
\text { RZ10, } \\
\text { and } \\
\text { RZ11 }\end{array}$ \\
\hline \multirow[t]{2}{*}{$\begin{array}{l}\text { Real estate } \\
\text { developer }\end{array}$} & \multirow[t]{2}{*}{2} & Jinrun & $\begin{array}{l}17 / 10 / \\
2016\end{array}$ & 33 mins & $\begin{array}{l}\text { Jinrun's office } \\
\text { building }\end{array}$ & RZ12 \\
\hline & & Rizhao Cheng Tou & $\begin{array}{l}20 / 10 / \\
2016\end{array}$ & 44 mins & $\begin{array}{l}\text { Rizhao } \\
\text { Chengtou's } \\
\text { office building }\end{array}$ & RZ13 \\
\hline \multirow[t]{2}{*}{$\begin{array}{l}\text { Industry } \\
\text { organization }\end{array}$} & \multirow[t]{2}{*}{1} & \multirow[t]{2}{*}{$\begin{array}{l}\text { Rizhao Solar Energy Industry } \\
\text { Association }\end{array}$} & $\begin{array}{l}18 / 10 / \\
2016\end{array}$ & 128 mins & $\begin{array}{l}\text { An unknown } \\
\text { restaurant }\end{array}$ & \multirow[t]{2}{*}{ RZ14 } \\
\hline & & & $\begin{array}{l}21 / 10 / \\
2016\end{array}$ & 94 mins & $\begin{array}{l}\text { Chengnan } \\
\text { Wangshi } \\
\text { restaurant }\end{array}$ & \\
\hline \multirow[t]{3}{*}{ NGO } & \multirow[t]{3}{*}{3} & $\begin{array}{l}\text { Rizhao Solar Culture } \\
\text { Association }\end{array}$ & $\begin{array}{l}18 / 10 / \\
2016\end{array}$ & 53 mins & $\begin{array}{l}\text { Rizhao } \\
\text { newspaper } \\
\text { office }\end{array}$ & RZ15 \\
\hline & & \multirow[t]{2}{*}{ Solar Vision } & $\begin{array}{l}24 / 10 / \\
2016\end{array}$ & 140 mins & $\begin{array}{l}\text { Solar Vision's } \\
\text { office }\end{array}$ & RZ16 \\
\hline & & & $\begin{array}{l}25 / 10 / \\
2016\end{array}$ & 62 mins & $\begin{array}{l}\text { Solar Vision's } \\
\text { office }\end{array}$ & RZ17 \\
\hline \multirow[t]{7}{*}{ End-user } & \multirow[t]{7}{*}{10} & \multirow[t]{4}{*}{ Residents } & $\begin{array}{l}13 / 10 / \\
2016\end{array}$ & 15 mins & $\begin{array}{l}\text { Office of Wenxin } \\
\text { Photography }\end{array}$ & RZ18 \\
\hline & & & $\begin{array}{l}18 / 10 / \\
2016\end{array}$ & 15 mins & $\begin{array}{l}\text { Electricity } \\
\text { Mansion }\end{array}$ & RZ19 \\
\hline & & & $\begin{array}{l}19 / 10 / \\
2016\end{array}$ & 32 mins & $\begin{array}{l}\text { Rizhao Renjia } \\
\text { restaurant }\end{array}$ & RZ20 \\
\hline & & & $\begin{array}{l}21 / 10 / \\
2016\end{array}$ & 170 mins & $\begin{array}{l}\text { Chengnan } \\
\text { Wangshi } \\
\text { restaurant }\end{array}$ & $\begin{array}{l}\text { RZ21, } \\
\text { RZ22 } \\
\text { and } \\
\text { RZ23 }\end{array}$ \\
\hline & & \multirow[t]{3}{*}{ Taxi driver } & $\begin{array}{l}13 / 10 / \\
2016\end{array}$ & 12 mins & Car & RZ24 \\
\hline & & & $\begin{array}{l}18 / 10 / \\
2016\end{array}$ & 21 mins & Car & RZ25 \\
\hline & & & $\begin{array}{l}20 / 10 / \\
2016\end{array}$ & 14 mins & Car & RZ26 \\
\hline
\end{tabular}


Table 4 List of interviews (Continued)

\begin{tabular}{|c|c|c|c|c|c|c|}
\hline Actor type & $\begin{array}{l}\text { Number of } \\
\text { Interviewees }\end{array}$ & Affiliation of interviewees & $\begin{array}{l}\text { Interview } \\
\text { date }\end{array}$ & $\begin{array}{l}\text { Interview } \\
\text { duration }\end{array}$ & $\begin{array}{l}\text { Interview } \\
\text { location }\end{array}$ & Coding \\
\hline & & & $\begin{array}{l}22 / 10 / \\
2016\end{array}$ & 67 mins & Car & RZ27 \\
\hline Total & 27 & & & & & \\
\hline \multicolumn{7}{|l|}{ Foshan } \\
\hline \multirow[t]{3}{*}{$\begin{array}{l}\text { Senior } \\
\text { executives of } \\
\text { a utility } \\
\text { company }\end{array}$} & 7 & $\begin{array}{l}3 \text { interviewees are senior } \\
\text { executives of the Marketing } \\
\text { and Sales Department, } \\
\text { Foshan Power Supply } \\
\text { Bureau, Guangdong Power } \\
\text { Grid Group }\end{array}$ & $\begin{array}{l}24 \text { March, } \\
2017\end{array}$ & 90 mins & $\begin{array}{l}\text { Office, Foshan } \\
\text { Power Supply } \\
\text { Bureau }\end{array}$ & $\begin{array}{l}\text { FS1, } \\
\text { FS2 } \\
\text { and } \\
\text { FS3 }\end{array}$ \\
\hline & & $\begin{array}{l}2 \text { interviewees are senior } \\
\text { executives of the Customer } \\
\text { Service department, Foshan } \\
\text { Power Supply Bureau, } \\
\text { Guangdong Power Grid } \\
\text { Group }\end{array}$ & $\begin{array}{l}24 \text { March, } \\
2017\end{array}$ & 90 mins & $\begin{array}{l}\text { Office, Foshan } \\
\text { Power Supply } \\
\text { Bureau }\end{array}$ & $\begin{array}{l}\text { FS4 } \\
\text { and } \\
\text { FS5 }\end{array}$ \\
\hline & & $\begin{array}{l}2 \text { interviewers are senior } \\
\text { executive of the Energy } \\
\text { Efficiency Service Centre, } \\
\text { Foshan Power Supply } \\
\text { Bureau, Guangdong Power } \\
\text { Grid Group (who are } \\
\text { responsible for renewable } \\
\text { energy applications) }\end{array}$ & $\begin{array}{l}24 \text { March, } \\
2017\end{array}$ & 90 mins & $\begin{array}{l}\text { Office, Foshan } \\
\text { Power Supply } \\
\text { Bureau }\end{array}$ & $\begin{array}{l}\text { FS6 } \\
\text { and } \\
\text { FS7 }\end{array}$ \\
\hline \multirow[t]{2}{*}{$\begin{array}{l}\text { Solar } \\
\text { installers }\end{array}$} & 2 & $\begin{array}{l}\text { Representative of solar } \\
\text { installer A in Foshan }\end{array}$ & $\begin{array}{l}24 \text { March, } \\
2017\end{array}$ & 90 mins & $\begin{array}{l}\text { Office, Dali } \\
\text { Town, Foshan }\end{array}$ & FS8 \\
\hline & & $\begin{array}{l}\text { Representative of solar } \\
\text { installer B in Foshan }\end{array}$ & $\begin{array}{l}24 \text { March, } \\
2017\end{array}$ & 90 mins & $\begin{array}{l}\text { Luonan Village } \\
\text { Office, } \\
\text { Nanzhuang } \\
\text { Town, Foshan }\end{array}$ & FS9 \\
\hline $\begin{array}{l}\text { Expert on } \\
\text { solar PV } \\
\text { technology }\end{array}$ & 1 & $\begin{array}{l}\text { A professor, the Guangzhou } \\
\text { Institute of Energy } \\
\text { Conversion }\end{array}$ & $\begin{array}{l}7 \text { January, } \\
2015\end{array}$ & 90 mins & $\begin{array}{l}\text { Office, } \\
\text { Guangzhou } \\
\text { Institute of } \\
\text { Energy } \\
\text { Conversion, } \\
\text { Guangzhou }\end{array}$ & FS10 \\
\hline $\begin{array}{l}\text { Solar house- } \\
\text { owner }\end{array}$ & 1 & $\begin{array}{l}\text { A householder in Dengxi } \\
\text { Village, Dali Town, Foshan }\end{array}$ & & 30 mins & $\begin{array}{l}\text { Home of the } \\
\text { interviewee, } \\
\text { Dengxi Village }\end{array}$ & FS11 \\
\hline Total & 11 & & & & & \\
\hline \multicolumn{7}{|l|}{ Wuxi } \\
\hline \multirow[t]{8}{*}{ Government } & 8 & $\begin{array}{l}\text { Wuxi Bureau of } \\
\text { Environmental Protection }\end{array}$ & $\begin{array}{l}22 / 11 / \\
2016\end{array}$ & 55 mins & office & WX1 \\
\hline & & $\begin{array}{l}\text { Wuxi Bureau of Foreign } \\
\text { Trade }\end{array}$ & $\begin{array}{l}22 / 11 / \\
2016\end{array}$ & 50 mins & office & $W \times 2$ \\
\hline & & $\begin{array}{l}\text { Wuxi Bureau of Economic } \\
\text { Development }\end{array}$ & $\begin{array}{l}23 / 11 / \\
2016\end{array}$ & 30 mins & office & WX3 \\
\hline & & $\begin{array}{l}\text { Wuxi Bureau of Housing and } \\
\text { Urban Development }\end{array}$ & $\begin{array}{l}23 / 11 / \\
2016\end{array}$ & 65 mins & office & WX4 \\
\hline & & Wuxi Bureau of Planning & $\begin{array}{l}10 / 04 / \\
2017\end{array}$ & 90 mins & office & WX5 \\
\hline & & (two interviewees) & $\begin{array}{l}11 / 04 / \\
2017\end{array}$ & 50 mins & office & WX6 \\
\hline & & $\begin{array}{l}\text { Wuxi Bureau of Science and } \\
\text { Technology }\end{array}$ & $\begin{array}{l}11 / 04 / \\
2017\end{array}$ & 50 mins & office & WX7 \\
\hline & & $\begin{array}{l}\text { Wuxi Development and } \\
\text { Reform Commission }\end{array}$ & $\begin{array}{l}23 / 11 / \\
2016\end{array}$ & 50 mins & office & WX8 \\
\hline
\end{tabular}


Table 4 List of interviews (Continued)

\begin{tabular}{|c|c|c|c|c|c|c|}
\hline Actor type & $\begin{array}{l}\text { Number of } \\
\text { Interviewees }\end{array}$ & Affiliation of interviewees & $\begin{array}{l}\text { Interview } \\
\text { date }\end{array}$ & $\begin{array}{l}\text { Interview } \\
\text { duration }\end{array}$ & $\begin{array}{l}\text { Interview } \\
\text { location }\end{array}$ & Coding \\
\hline \multirow[t]{2}{*}{ Manufacturer } & 2 & $\begin{array}{l}\text { Taihu new town PV } \\
\text { company }\end{array}$ & $\begin{array}{l}26 / 04 / \\
2017\end{array}$ & 40 mins & Coffee shop & WX9 \\
\hline & & Suntech Ltd. & $\begin{array}{l}26 / 04 / \\
2017\end{array}$ & 30 mins & Coffee shop & WX10 \\
\hline $\begin{array}{l}\text { Real estate } \\
\text { developer }\end{array}$ & 1 & Landsea & $\begin{array}{l}10 / 04 / \\
2017\end{array}$ & 30 mins & Coffee shop & WX11 \\
\hline \multirow[t]{2}{*}{$\begin{array}{l}\text { Industry } \\
\text { organization }\end{array}$} & 2 & $\begin{array}{l}\text { Taihu new town High-tech } \\
\text { company, }\end{array}$ & $\begin{array}{l}13 / 04 / \\
2017\end{array}$ & 40 mins & office & $W \times 12$ \\
\hline & & $\begin{array}{l}\text { Wuxi Planning and Design } \\
\text { Institution }\end{array}$ & $\begin{array}{l}10 / 04 / \\
2017\end{array}$ & 160 mins & office & WX13 \\
\hline NGO & 1 & $\begin{array}{l}\text { Chong' an Housing } \\
\text { Association }\end{array}$ & $\begin{array}{l}11 / 04 / \\
2017\end{array}$ & 50 mins & Coffee shop & WX14 \\
\hline \multirow[t]{2}{*}{ End-user } & 6 & Chong'an residents (4) & $\begin{array}{l}11 / 04 / \\
2017\end{array}$ & 50 mins & Coffee shop & $\begin{array}{l}\text { WX15- } \\
18\end{array}$ \\
\hline & & $\begin{array}{l}\text { Taihu new town residents } \\
\text { (2) }\end{array}$ & $\begin{array}{l}13 / 04 / \\
2017\end{array}$ & 40 mins & Coffee shop & $\begin{array}{l}\text { WX19- } \\
20\end{array}$ \\
\hline Total & 20 & & & & & \\
\hline
\end{tabular}

technologies; however, overall transitions result from the combined effect of multiple plans, programs, and policies implemented over time in different locations. Attributing the success of the solar industry to supportive policies, such as subsidies, feed-in tariffs, or preferential taxes, overlooks relevant factors that facilitate the adoption and spread of technology such as the rise of environmental concerns in political agendas, the demands of the built environment, and cultural practices.

Moreover, evidence of place-based transitions towards solar energy is not evidence of an overall low carbon transition in China. In Wuxi, carbon emissions and energy use continue to climb despite solar success. Rising energy demand is associated with a rapidly growing construction sector and increasing reliance on private transport (Dienst et al. 2013). In Rizhao, residential carbon emissions are dwarfed by the emissions of the industrial sector. The emission reductions realized through the shift to residential solar water heaters are thus imperceptible in aggregate data on urban energy consumption (Shandong Provincial Yearbook, 1978-2010). The nascent solar industry in Foshan has not yet displaced more polluting industries that characterized the growth of the city over three decades. Enthusiasm for solar technologies emerges in the context of heavy dependence on fossil fuels. This context prevents a broader energy transition while it also acts as a motivation to support renewable development and adoption. Nevertheless, this reflection tempers enthusiasm about the urban energy transition in China and its impact on a national transition.

The comparative analysis warns against a premature celebration of China's global leadership in environmental policy because these sustainability strategies adopt models that accommodate well-established hierarchical paradigms of governance (cf., Shin 2018; Westman and Castán Broto 2019). The DUET framework provides an antidote against narratives of neatly planned, state-led sustainable transformations. The case of China is aligned with previous studies that reveal the complexity of urban energy transitions (Frantzeskaki et al. 2017; Frantzeskaki et al. 2018; Roorda et al. 2014). Each transition trajectory reveals the progressive alignment over time of multiple actors, 
particularly between local industrial strategies and urban development priorities. Governing urban transitions, therefore, requires the simultaneous orchestration of actors and materials. However, none of these cases provides a ready-made model for urban energy transitions in China or elsewhere. Instead, the cases support the conclusion that identifying low-carbon pathways depends on a place-based analysis of the dynamics of innovation, urban politics, and the socio-spatial factors that shape the urban energy transition.

\section{Abbreviations}

DUET: Dimensions of Urban Energy Transitions; FIT: Feed-in tariff; GDP: Gross Domestic Product; Km: Kilometre; Kw: Kilowatt; PV : Photovoltaic; R\&D: Research And Development; RMB: Chinese Yuan; SWH : Solar water heater

\section{Acknowledgements}

The authors wish to thank Murray Fraser for his support.

\section{Authors' contributions}

VCB conceived and coordinated the paper. VCB, DM, FZ, PH, KL, and LW conceived and wrote the theoretical framework in collective discussions. DM, FZ, PH, KL, and LW developed the case study material following the agreed theoretical framework. VCB, DM, FZ, PH, KL, and LW developed the analysis and argument. VCB, DM, FZ, PH, KL, and LW wrote and edited the paper. The authors read and approved the final manuscript.

\section{Funding}

The research reported in this paper was funded with a small grant from the Bartlett Faculty of the Built Environment, University College London. Support for the comparative analysis and writing was provided by a European Research Council Grant for the project Low Carbon Action in Ordinary Cities (Number: 804051 — LO-ACT, PI: Castán Broto).

\section{Availability of data and materials}

The paper uses a qualitative dataset that has been summarized and synthetized in the case studies. The case studies stand alone and can be provided independently from the paper upon request.

\section{Ethics approval and consent to participate}

The project was conducted following the ethical guidelines at UCL, while also respecting any ethical codes relevant to the context of research in China. Since the project only involved interviews with individuals in their official capacity, and no members of vulnerable groups were targeted in the interviews, the proposal went through the 'Low Risk Application' approval process which, at the time (2016), did not required formal registration with the Ethics Committee.

\section{Consent for publication}

Informed consent to participate in the study was obtained in every case. No personal information of any kind is included in the results.

\section{Competing interests}

None identified.

\section{Author details}

${ }^{1}$ Urban Institute, University of Sheffield, 219 Portobello, S1 4PD, Sheffield, UK. ${ }^{2}$ Asian Energy Studies Centre; Department of Geography, Hong Kong Baptist University, Room 1202, 12/F, Academic and Administration Building, 15 Baptist University Road, Kowloon Tong, Hong Kong, Hong Kong. ${ }^{3}$ Bartlett School of Planning, University College London, 14 Upper Woburn PI, Bloomsbury, London WC1H ONN, UK.

Received: 3 October 2019 Accepted: 5 August 2020

Published online: 11 September 2020

\section{References}

Bergek A, Hekkert M, Jacobsson S, Markard J, Sandén B, Truffer B. Technological innovation systems in contexts: conceptualizing contextual structures and interaction dynamics. Environ Innov Soc Trans. 2015;16:51-64.

Berkhout F, Angel D, Wieczorek AJ. Sustainability transitions in developing Asia: are alternative development pathways likely? Technol Forecast Soc Chang. 2009;76:215-7.

Binz C, Truffer B, Coenen L. Why space matters in technological innovation systems—-mapping global knowledge dynamics of membrane bioreactor technology. Res Policy. 2014;43:138-55.

Binz C, Truffer B, Coenen L. Path creation as a process of resource alignment and anchoring: industry formation for on-site water recycling in Beijing. Econ Geogr. 2016;92:172-200.

Boschma R. Proximity and innovation: a critical assessment. Reg Stud. 2005;39:61-74.

Bulkeley H, Betsill MM. Revisiting the urban politics of climate change. Environ Politics. 2013;22:136-54

Bulkeley H, Castán Broto V, Hodson M, Marvin S. Cities and low carbon transitions. London: Routledge; 2010. 
Bulkeley H, Coenen L, Frantzeskaki N, Hartmann C, Kronsell A, Mai L, et al. Urban living labs: governing urban sustainability transitions. Curr Opin Environ Sustain. 2016;22:13-7.

Bulkeley HA, Castán Broto V, Edwards GA. An urban politics of climate change: experimentation and the governing of sociotechnical transitions. London: Routledge; 2014

Castan Broto V. Urban energy landscapes. Cambridge: Cambridge University Press; 2019.

Castán Broto V, Bulkeley H. Maintaining climate change experiments: Urban political ecology and the everyday reconfiguration of urban infrastructure. Int J Urban Reg Res. 2013;37:1934-48.

Chen J, Zhang D, Xie P, Wang Q, Ma Z. Simultaneous determination of microcystin contaminations in various vertebrates (fish, turtle, duck and water bird) from a large eutrophic Chinese Lake, Lake Taihu, with toxic Microcystis blooms. Sci Total Environ. 2009:407:3317-22.

Coenen L, Benneworth P, Truffer B. Toward a spatial perspective on sustainability transitions. Res Policy. 2012;41:968-79.

Coenen L, Truffer B. Places and spaces of sustainability transitions: geographical contributions to an emerging research and policy field. Eur Plan Stud. 2012;20:367-74.

Dienst C, Schneider C, Xia C, Saurat M, Fischer T, Vallentin D. On track to become a low carbon future city? First findings of the integrated status quo and trends assessment of the pilot city of Wuxi in China. Sustainability. 2013;5:3224-43.

Ellabban O, Abu-Rub H, Blaabjerg F. Renewable energy resources: current status, future prospects and their enabling technology. Renew Sustain Energy Rev. 2014;39:748-64.

Foshan Statistics Bureau. 2016 Foshan statistics handbook (2016年佛山统计年鉴); 2017.

Foxon TJ. A coevolutionary framework for analysing a transition to a sustainable low carbon economy. Ecol Econ. 2011;70: 2258-67.

Frantzeskaki N, Castán Broto V, Coenen L, Loorbach D. Urban sustainability transitions. London: Taylor \& Francis; 2017.

Frantzeskaki N, Hölscher K, Bach M, Avelino F. Co-creating sustainable Urban futures: a primer on applying transition Management in Cities International Publishing. Geneva: Springer; 2018.

GCGET. A New World: the geopolitics of energy transformations; 2019. The Global Commission on the Geopolitics of Energy Transformation and IRENA.

Geels FW, Schot J. Typology of socio-technical transition pathways. Res Policy. 2007:36:399-417.

Guangdong DRC. Guangdong solar photovoltaic power generation development plan (2014 to 2020); 2014. Guangdong development and reform Comission. http://www.gddpc.gov.cn/fzgggz/nyfz/201503/t20150309_305031.html (in Chinese), Guangzhou, China.

Hagerman S, Jaramillo P, Morgan MG. Is rooftop solar PV at socket parity without subsidies? Energy Policy. 2016;89:84-94.

Hansen T, Coenen L. The geography of sustainability transitions: review, synthesis and reflections on an emergent research field. Environ Innov Soc Trans. 2015;17:92-109.

Hekkert MP, Suurs RA, Negro SO, Kuhlmann S, Smits RE. Functions of innovation systems: a new approach for analysing technological change. Technol Forecast Soc Chang. 2007;74:413-32.

Hodson M, Geels FW, McMeekin A. Reconfiguring urban sustainability transitions, analysing multiplicity. Sustainability. 2017;9:299.

Hong L, Zhou N, Fridley D, Raczkowski C. Assessment of China's renewable energy contribution during the 12th five year plan. Energy Policy. 2013;62:1533-43.

Huang P, Castán Broto V. The interdependence between urban processes and energy transitions: the dimensions of Urban energy transitions (DUET) framework; 2018. Environmental Innovation and Societal Transitions.

Huang P, Castán Broto V, Liu Y. From "transitions in cities" to "transitions of cities": the diffusion and adoption of solar hot water systems in urban China. Energy Res Soc Sci. 2018a;36:156-64.

Huang P, Castán Broto V, Liu Y, Ma H. The governance of urban energy transitions: a comparative study of solar water heating systems in two Chinese cities. J Clean Prod. 2018b;180:222-31.

IEA. Energy technology perspectives 2015: Mobilising innovation to accelerate climate action. Paris: OECD; 2015.

Kemp R, Parto S. Governance for sustainable development: moving from theory to practice. Int J Sustain Dev. 2005;8:12-30.

Kemp R, Rotmans J. In: systems, T.e.i, editor. The management of the co-evolution of technical, environmental and social systems. Berlin: Springer; 2005. p. 39-61.

Kim K, Kim Y. Role of policy in innovation and international trade of renewable energy technology: empirical study of solar PV and wind power technology. Renew Sustain Energy Rev. 2015;44:717-27.

Kivimaa P, Hyysalo S, Boon W, Klerkx L, Martiskainen M, Schot J. Passing the baton: how intermediaries advance sustainability transitions in different phases. Environ Innov Soc Trans. 2019;31:110-25.

Liu D, Shiroyama H. Development of photovoltaic power generation in China: a transition perspective. Renew Sustain Energy Rev. 2013;25:782-92.

Lo K, Castán Broto V. Co-benefits, contradictions, and multi-level governance of low-carbon experimentation: leveraging solar energy for sustainable development in China. Glob Environ Chang. 2019;59:101993.

Loorbach D, Shiroyama H. The challenge of sustainable Urban development and transforming cities in. In: Loorbach D, Shiroyama H, Wittmayer JM, Fujino J, Mizuguchi S, editors. Governance of Urban sustainability transitions: European and Asian experiences. Tokyo: Springer; 2016. p. 2-12.

Mah D, Hills P. An international review of local governance for climate change: implications for Hong Kong. Local Environ. 2016;21:39-64.

Marletto G. Car and the city: socio-technical transition pathways to 2030. Technol Forecast Soc Chang. 2014;87:164-78.

McDowall W. Exploring possible transition pathways for hydrogen energy: a hybrid approach using socio-technical scenarios and energy system modelling. Futures. 2014;63:1-14.

Monstadt J, Wolff A. Energy transition or incremental change? Green policy agendas and the adaptability of the urban energy regime in Los Angeles. Energy Policy. 2015;78:213-24.

Moore T, Horne R, Gleeson BJ, de Haan F. Urban sustainability transitions. Singapore: Springer Nature Singapore; 2018

Morlet C, Keirstead J. A comparative analysis of urban energy governance in four European cities. Energy Policy. 2013;61:852-63.

NEA. Experience from the distributed solar PV demonstration zone in Sanshui Industrial Park (三水工业园区建设分布式光 伏经验 ). Beijing: National Energy Administrationhttp://www.nea.gov.cn/2014-08/20/c_133619551.htm (In Chinese); 2014.

Negro SO, Hekkert MP, Smits RE. Explaining the failure of the Dutch innovation system for biomass digestion-a functional analysis. Energy Policy. 2007;35:925-38. 
Oberheitmann A. Development of a low carbon economy in Wuxi city. Am J Clim Chang. 2012;1:64.

People's Government of Sanshui. Sanshui Industrial Park becomes one of the first National Solar PV demonstration zones (三 水工业园区入选全国首批分布式光伏发电示范区). Foshan: People's Government of Sanshuihttp://www.ss.gov.cn/ mlss/ssnj/2014/02\%E7\%BB\%BC\%E8\%BF\%B0/S0203.htm (In Chinese); 2014.

Philipps S, Grossi F, Coles N. Leverage points for low carbon entrepreneurship in Wuxi; 2012. Low Carbon Future Cities Report 4.

REN21. Renewables 2019 global status report. Paris: REN21 Secretariat; 2019

Roorda C, Wittmayer J, Henneman P, van Steenbergen F, Frantzeskaki N, Loorbach D. Transition management in the urban context. Guidance manual. Rotterdam: DRIFT, Erasmus University Rotterdam; 2014.

Rosenbloom D, Berton H, Meadowcroft J. Framing the sun: a discursive approach to understanding multidimensional interactions within socio-technical transitions through the case of solar electricity in Ontario, Canada. Res Policy. 2016; 45(6):1275-90.

Rotmans J, Kemp R, Asselt M. More evolution than revolution: transition management in public policy. Foresight. 2001;3:15-31.

Rutherford J, Coutard O. Urban energy transitions: places, processes and politics of socio-technical change. Urban Stud. 2014; 51:1353-77.

Rydin Y, Turcu C, Chmutina K, Devine-Wright P, Goodier C, Guy S, et al. Urban energy initiatives: the implications of new urban energy pathways for the UK. Network Industries Quarterly. 2012;14:20-3.

Rydin Y, Turcu C, Guy S, Austin P. Mapping the co-evolution of urban energy systems: pathways of change. Environ Plan A. 2013:45:634-49.

Shin K. Environmental policy innovations in China: a critical analysis from a low-carbon city. Environ Politics. 2018;27(5):830-51.

Sun P, Nie P-Y. A comparative study of feed-in tariff and renewable portfolio standard policy in renewable energy industry. Renew Energy. 2015;74:255-62

Turnheim B, Berkhout F, Geels F, Hof A, McMeekin A, Nykvist B, et al. Evaluating sustainability transitions pathways: bridging analytical approaches to address governance challenges. Glob Environ Chang. 2015;35:239-53.

Urban F, Geall S, Wang Y. Solar PV and solar water heaters in China: different pathways to low carbon energy. Renew Sustain Energy Rev. 2016;64:531-42.

Verbong GP, Geels FW. Exploring sustainability transitions in the electricity sector with socio-technical pathways. Technol Forecast Soc Chang. 2010;77:1214-21.

Westman LK, Castán Broto V. Techno-economic rationalities as a political practice in urban environmental politics in China. Environ Planning C: Politics Space. 2019;37(2):277-97.

Westman LK, Castán Broto V, Huang P. Revisiting multi-level governance theory: politics and innovation in the urban climate transition in Rizhao, China. Polit Geogr. 2019;70:14-23.

Wieczorek AJ, Raven R, Berkhout F. Transnational linkages in sustainability experiments: a typology and the case of solar photovoltaic energy in India. Environ Innov Soc Trans. 2015;17:149-65.

Yin Y, Olsson AR, Håkansson M. The role of local governance and environmental policy integration in Swedish and Chinese eco-city development. J Clean Prod. 2016;134:78-86.

Yuan X, Zuo J. Transition to low carbon energy policies in China-from the five-year plan perspective. Energy Policy. 2011; 39(6):3855-9.

Zhang N, Wang B, Liu Z. Carbon emissions dynamics, efficiency gains, and technological innovation in China's industrial sectors. Energy. 2016;99:10-9.

Zhu, W., 2017. Paper-packing market reshuffles. China Daily. https://www.chinadaily.com.cn/business/2017-09/01/content_314 00831.htm

Publisher's Note

Springer Nature remains neutral with regard to jurisdictional claims in published maps and institutional affiliations.

Ready to submit your research? Choose BMC and benefit from:

- fast, convenient online submission

- thorough peer review by experienced researchers in your field

- rapid publication on acceptance

- support for research data, including large and complex data types

- gold Open Access which fosters wider collaboration and increased citations

- maximum visibility for your research: over $100 \mathrm{M}$ website views per year

At $B M C$, research is always in progress.

Learn more biomedcentral.com/submissions 